УДК 925 : 159.923

Ivashkevych Eduard, Doctor of Psychology, Professor of the Department of General Psychology and Psychological diagnostics of Rivne State University of the Humanities (Rivne, Ukraine) natasha1273@ukr.net

\title{
SOCIAL INTELLIGENCE OF THE TEACHERS IN THE CONTEXT OF UNDERSTANDING BY THEM THE MEANING OF PROVERBS AND SAYINGS
}

\section{Summary}

In this article social intelligence of teachers of pre-school educational establishments was analyzed in the context of understanding by the person the meaning of proverbs and sayings which include socially determined sense. The author of the article considers the most important criteria for productive functioning of the teacher's social intelligence so called successful solution of human social non-standard (including - the most original) tasks, as well as the success of a specialist in the implementation of pedagogical activities. The first involves the mandatory functioning of decision-making mechanism. This mechanism, as well as other functional mechanisms of social intelligence (the mechanism of decentralization, the mechanism of intellectual initiation, reflexive mechanisms, etc.), are predetermined by individual cognition, for example, attention, imagination, perception, memory, thinking. That's why we have a deal with automatism of functional mechanisms of social intelligence. In the field of mnemonic experience (the mnemonic aspect of social intelligence) conscious experiences are accompanied by a sense of subjective evidence of what had been happened.

The mechanism of making a socially balanced decision was analyzed taking into account the complexity, non-standard social situation. This mechanism allows the teacher to move away from intellectual formations of a person as a representative of a certain national-cultural space, and, avoiding prototypes and ethnic stereotypes, to choose the most appropriate for this social situation the 
mechanism for updating the reflection of the subjective space, the cognitive style of carrying out professional activity, and building a development logic situations of interpersonal interaction, taking into account moral and ethnic norms, values, etc., to make a socially weighed decision. The latter will contribute not only because the teacher will adequately and empathically interact with other actors (colleagues and trustees), but also, including the achievement of the teacher of success in the professional activity. In the functional aspect we are talking about the amplification of social intelligence.

The empirical results of our research allow to distinguish the following tendencies: 1) there are no statistically significant differences in the results of teachers of different groups (including the directors of pre-school educational institutions) according to the success of their interpretation of social meaning at a generalized level; 2) teachers of pre-school educational institutions prevail over the following levels of understanding the meaning of proverbs (sayings), as the "level of concrete understanding" and the "level of global understanding".

Key words: social intelligence, individual cognition, attention, imagination, perception, memory, thinking.

Івашкевич Едуард Зенонович, доктор психологічних наук, доцент, професор кафедри загальної психології та психодіагностики Рівненського державного гуманітарного університету (Рівне, Україна)

\section{СОЦАЛЬНИЙ ІНТЕЛЕКТ ПЕДАГОГІВ В КОНТЕКСТІ} РОЗУМІННЯ НИМИ ПРИСЛІВ'ЇВ ТА ПРИКАЗОК

\section{Анотація}

В статті соціальний інтелект педагогів дошкільних навчальних закладів проаналізовано в контексті розуміння особистістю значення прислів”їв та приказок, які вміщують так званий «соціальний» сенс. Автор статті вважає, що критеріями продуктивного функціонування соціального інтелекту педагога $є$ успішне розв'язання людиною соціальних нестандартних (в тому числі - оригінальних) задач та завдань, а також успішність фахівця в 
реалізації педагогічної діяльності. Зазначено, що перше передбачає обов'язкове функціонування механізму прийняття рішення. Обгрунтовано, що останній, як і інші функціональні механізми соціального інтелекту (механізм децентрації, механізм інтелектуальної ініціації, рефлексивні механізми тощо), зумовлюються когніціями особистості, наприклад, увагою, уявою, сприйманням, пам'яттю, мисленням та ін. Визначено, що в сфері мнемічного досвіду (мнемічний аспект соціального інтелекту) усвідомлені переживання супроводжуються почуттям суб'єктивної очевидності того, що відбувається. Саме за умов експліцитної наявності таких переживань суб’єкт здатний сам собі дати звіт про власний пережитий досвід.

Механізм прийняття соціально виваженого рішення було проаналізовано 3 урахуванням складності, нестандартності соціальної ситуації. Зазначено, що даний механізм дозволяє педагогу відійти від інтелектуальних утворень людини як представника певного національно-культурного простору, та, уникаючи прототипів та етнічних стереотипів, обрати найбільш доцільний даній соціальній ситуації механізм актуалізації відображення суб'єктивного простору, когнітивний стиль виконання професійної діяльності, та, вибудовуючи логіку розвитку ситуацій міжособистісної взаємодії, ураховуючи моральні та етнічні норми, цінності тощо, прийняти соціально виважене рішення. Останнє сприятиме не лише тому, що педагог буде адекватно та емпатійно здійснювати взаємодію 3 іншими суб'єктами (колегами та підопічними особами), а й, в тому числі, досягненню педагогом успіху в професійній діяльності. У функціональному аспекті йдеться про ампліфікацію соціального інтелекту.

Отримані емпіричні результати проведеного дослідження дозволили виділити наступні тенденції: 1) немає статистично значущої різниці в результатах педагогів різних груп (в тому числі - i керівників дошкільних навчальних закладів) за успішністю інтерпретації соціального смислу на прислів “їв та приказок; 2) у педагогів дошкільних навчальних закладів переважають результати за такими рівнями розуміння сенсу прислів’їв 
(приказок), як «рівень конкретного розуміння» та «рівень глобального розуміння».

Ключові слова: соціальний інтелект, індивідуальне пізнання, увага, уява, сприйняття, пам'ять, мислення.

Ивашкевич Эдуард Зенонович, доктор психологических наук, доцент, профессор кафедры общей психологии и психодиагностики Ровенского государственного гуманитарного университета (Ровно, Украина)

\title{
СОЦИАЛЬНЫЙ ИНТЕЛЛЕКТ ПЕДАГОГОВ В КОНТЕКСТЕ ПОНИМАНИЯ НИМИ ПОСЛОВИЦ И ПОГОВОРОК
}

\begin{abstract}
Аннотация
В статье социальный интеллект педагогов дошкольных учебных заведений проанализированы в контексте понимания личностью смысла пословиц и поговорок, содержащих так называемое «социальное» наполнение. Автор статьи считает, что критериями продуктивного функционирования социального интеллекта педагога является успешное решение человеком социальных нестандартных (в том числе - оригинальных) заданий и задач, а также успешность специалиста в реализации педагогической деятельности. Определено, что первое предусматривает обязательное функционирование механизма принятия решения. Обосновано, что данный механизм, как и другие функциональные механизмы социального интеллекта (механизм децентрации, механизм интеллектуальной инициации, рефлексивные механизмы и т.д.), обусловлены когнициями личности, например, вниманием, воображением, восприятием, памятью, мышлением и др. Определено, что в сфере мнемического опыта (мнемический аспект социального интеллекта) осознанные переживания сопровождаются чувством субъективной очевидности происходящего. Именно в условиях эксплицитного наличия таких переживаний субъект способен сам себе дать отчёт о личностно пережитом опыте.
\end{abstract}


Механизм принятия социально взвешенного решения был проанализирован с учётом сложности, нестандартности социальной ситуации. Указано, что данный механизм позволяет педагогу отойти от интеллектуальных новообразований человека как представителя определённого национально-культурного пространства, и, избегая прототипов и этнических стереотипов, выбрать наиболее целесообразный данной социальной ситуации механизм актуализации отображения субъективного пространства, когнитивный стиль выполнения профессиональной деятельности, и, выстраивая логику развития ситуаций межличностного взаимодействия, учитывая моральные и этнические нормы, ценности и т.п., принять социально взвешенное решение. Последнее будет способствовать не только потому, что педагог будет адекватно и эмпатийно осуществлять взаимодействие с другими субъектами (коллегами и подопечными лицами), но и, в том числе, достижению педагогом успеха в профессиональной деятельности. В функциональном аспекте речь идет об амплификации социального интеллекта.

Полученные эмпирические результаты проведённого исследования позволили выделить следующие тенденции: 1) не определено статистически значимой разницы в результатах педагогов разных групп (в том числе - и руководителей дошкольных учебных заведений) по успеваемости интерпретации социального смысла пословиц и поговорок; 2) у педагогов дошкольных учебных заведений преобладают результаты по таким уровням понимания смысла пословиц (поговорок), как «уровень конкретного понимания» и «уровень глобального понимания».

Ключевые слова: социальный интеллект, индивидуальное познание, внимание, воображение, восприятие, память, мышление.

Problem's statement and the actuality of the research. Social intelligence of the person is a kind of psychological instrument for providing a person with his/her own effective life, therefore, he/she is organized in a special way, but not as if it is 
separated from the social activity of the subject. In this case, the activity of the person, his/her position of subjectivity in relation to the society appears not only and not so much that the person contributes to a somewhat general, integral and social, but that the person is able to outside the direct coordination with all representatives of the society to create its own system of ways of interaction with other people, so-called socially determined interpretation complex. Such approach has to solve the essence of social intelligence and it is particularly important for pedagogical practice. Indeed, in the structure of the person social intelligence already has a certain repertoire of stereotypical methods, techniques, means that allow the man to establish contact with other people and to provide optimal interaction, even when, for example, cognitive empathy is reduced, or if the subject is insufficiently developed his/her ability to generalize and rationalize, or do not coincide with value orientations, moral and ethical guidance in subjects of social interaction. Social intelligence allows a deeper understanding of another person. At the same time, we predict that there is a certain set of basic dynamic structures of social intelligence that allow a person to adequately and empathically interact with other actors of social interaction. In such a way the topic of this research is so actual.

The purpose of the research. In this article we've to analyze concept of "intelligence" in the broad and narrow senses. Also the second task of our article is to arrange the structure of social intelligence. And the third task of our research is to propose the ways of the development the social intelligence of the teachers because of proposing socially balanced decision in the meaning of understanding proverbs and sayings (analyzing and understanding complex, non-standard social situation which are in the background of proverbs and sayings).

Presenting the material of the research. We consider the concept of "intelligence" in the broad and narrow senses. If we talk about the broad meaning of "intelligence", we mean about only one intelligence, the intellectual sphere of the person in general. In this sense, the intelligence of a person can be described as a hierarchical system that has several levels. The first level is the level of 
functioning of cognitions, to which psychologists refer the main psychical processes (sensation, perception, memory, attention, which, in turn, "control" the course of cognitive activity), as well as thinking and imagination, speech and dialogical interaction (R.Sternberg [16]; M.Smulson [8]; L.Zasekina [1]). The second level of intelligence is the level of metacognitions (metacognitive integrators, "secondary" mental processes), among which the main ones are intellectual initiation (self-statement of the problem), reflection, decentralization, intellectual strategies and abilities (abilities and competences), as well as metacognitive monitoring, intuition, intellectual atheist (values, meanings) (H.Elliott [12]). The first and the second levels of intelligence, in our opinion, are fully understood by the person who carries out intellectual activity. The third level of intelligence amplifies the characteristics of both the first and the second levels, while intellectual activity is carried out mainly at an unconscious level, a level that approximates a person to use of automated skills and abilities. The next, the fourth level, is the level of meta-intellectual activity, which explodes the creative achievements of the person. Thanks to this fourth level of intelligence a person is able to establish interaction not only with different objects and other people, but also with the world as a whole, thus expanding the limits of his/her intellect and starting a dialogue with the creative beginning of the world.

Let's describe the fundamental results of the researches according to the structure of social intelligence. Thus, in psychological studies there are several approaches in accordance with the definition of the structure of social intelligence:

- Cognitive-conative approach (J.Guilford [14]; G.Allport [10]; R.Thorndike [17]; O.Chesnokova [9]), which focuses on structural components of social intelligence, such as: operations (assessments, convergent thinking, divergent thinking, memory, cognition); categories describing the content characteristics of social intelligence (figurative, symbolic, semantic and conatative characteristics); categories describing the results of processing by the subject of social information (elements, classes, interpersonal relationships, systems, transformations, predictions). 
- Interpersonal Approach (V.Novikov [5]; T.Hunt [15]), which emphasizes the structure of social intelligence, which contains internal-personality and interpersonal intelligence within the paradigm of the theories of multi-intelligence by H.Gardner (H.Gardner [13]).

- Competent approach that considers social intelligence as cognitive competence (which in turn includes cognitive abilities) (N.Cantor \& J.Kihlstrom [11]);

- Socio-integrative approach which emphasizes such structural components of social intelligence as social sensitivity, social perception, social memory, social thinking, etc. (N.Klyueva \& Yu.Kasatkina [2]; V.Labunskaya [3]; H.Mikhailova [4]).

We consider the criteria for the productive functioning of the teacher's social intelligence as a successful solution to human social non-standard (including original) tasks, as well as the success of a specialist in the implementation of pedagogical activities. The first involves the mandatory functioning of the decision-making mechanism. The mechanism of decision-making, as well as other functional mechanisms of social intelligence (the mechanism of decentralization, the mechanism of intellectual initiation, reflexive mechanisms, etc.) are proved in the researches of M.Smulson [6; 7], which, above all, are predetermined by individual cognition, for example, attention, imagination, perception, memory, thinking, etc., can be understood by a teacher, but may not be realized, and then it is about automatism of functional mechanisms of social intelligence. In the field of mnemonic experience (the mnemonic aspect of social intelligence) conscious experiences are accompanied by a sense of subjective evidence of what is happening. It is precisely in the case of the explicit existence of such experiences that the subject is able to give himself/herself a report on his/her own experience. Confirmation of "subjective awareness" is a psychological concept that is widely used in scientific research: "direct experience", "personally significant experience", "professionally significant experience", "subjective experience", etc. The term "awareness" will denote exclusively the ended result, the integral psychic product of active intellectual activity. In other words, awareness is the result of our 
research, in particular, the social intelligence of the person. The concept of "awareness" is empirical, but, unlike other empirical concepts used in psychology, is not partial. This is the so-called "complex" concept, which denotes a wide range of empirical phenomena and categories that relate to different cognitive spheres of the person, for example, to the sensory, perceptual, mental spheres of representation and human motor activity. Therefore, the concept of "awareness" is equally appropriate to refer to the facts of awareness of tactile or acoustic influence, and to name the result of reproduction of previously learned information, and, for example, to state the fact of visual representation of any object. Understanding, of course, can have its own specificity, depending on the nature of intellectual activity. Thus, awareness during the perception of oral speech, of course, differs from the perception of the solution found in the nonstandard social task. However, if we are talking about such complex phenomenon as social intelligence, then as a rule, any fact that is perceived by a person is the result of unconscious intellectual activity. This activity, in turn, is carried out with the aid of well-known functional mechanisms, one of which is the mechanism for making a socially balanced solution.

The mechanism of making a socially balanced decision should be analyzed taking into account the complexity, non-standard social situation. This mechanism allows the teacher to move away from intellectual formations of a person as a representative of a certain national-cultural space, and, avoiding prototypes and ethnic stereotypes, to choose the most appropriate for this social situation the mechanism for updating the reflection of the subjective space, the cognitive style of carrying out professional activity, and building a development logic situations of interpersonal interaction, taking into account moral and ethnic norms, values, etc., to make a socially weighed decision. The latter will contribute not only because the teacher will adequately and empathically interact with other actors (colleagues and trustees), but also, including the achievement of the teacher of success in the professional activity. In the functional aspect we are talking about the amplification of social intelligence. 
Methods and methodical instrumentation of the research. The first phase of the experiment was carried out during 2005. The method of the research at this stage was the observation of teachers of preschool establishments, the selection of methodical tools for empirical research. The second, empirical stage of our study was carried out during 2006-2008. The following methods were used in the research: 1) general scientific methods (analysis, comparison, generalization); 2) the psychodiagnostic method, which was provided using the test of J.Gilford and M.O'Sullivan "Research of Social Intelligence", verbal and figurative subtest "Methods of studying divergent thinking" by P.Torrens, J.Gilford (in the modification of O.Tunik); associative experiment (using the method of B.Zeygarnik "Understanding the portable value of proverbs and metaphors"; 3) mathematical and statistical methods (statistical estimations of distribution parameters, x-Pearson criterion, checking of statistical hypotheses by means of parametric t-Student's criteria and the non-parametric U-criterion Manna-Whitney, the r-Spearman correlation coefficient).

Also, to determine the psychological type of the teacher's person we used: a questionnaire by V.Minyarov; typographic questionnaire MBTI; personal questionnaire of CPI; a questionnaire for evaluation of personal and business professional-important qualities of the person (T.Bazarov); a questionnaire for evaluation of interpersonal admissibility (N.Baharev); a questionnaire for evaluation of assessing the complex of productivity in managerial situations (R.Scock); the questionnaire proposed by us for the purpose of diagnosing difficulties of interaction of teachers with other people.

Therefore, 114 respondents were evenly distributed into groups:

E1 - 16 teachers of the II-d and the III-d categories (the experience of work is from 5 to 10 years, age is up to 30 years) of regional cities ( 5 respondents of the garden № 2 of Rivne, 5 educators of the garden № 5 of Kharkiv and 6 teachers of the garden № 11 from Odessa, Ukraine);

E2 - 18 teachers of the I-st category (the experience of work is from 10 to 15 years, age is from 30 to 37 years) of regional cities ( 7 respondents of the garden № 
2 of Rivne, 6 teachers of the garden № 5 of Kharkiv and 5 teachers of the garden № 11 of Odessa, Ukraine);

E3 - 15 teachers of the highest category (the experience of work is from 15 years and more, age is from 37 years) of regional cities ( 5 respondents of the kindergarten № 2 of Rivne, 5 educators of the garden № 5 of Kharkov and 5 teachers of the garden № 11 of Odessa, Ukraine);

E4 - 13 teachers of the I-st category (the experience of work is from 5 to 10 years, age is up to 30 years) of regional towns (4 respondents from the town of Zdolbuniv of Rivne region, kindergarten № 1; 5 tutors of Shepetovka, Khmelnytskyi region, kindergarten № 2; 4 respondents from the town of Zdolbuniv, Rivne region, kindergarten № 5, Ukraine);

E5 - 14 teachers of the II-d category (the experience of work is from 10 to 15 years, age is from 30 to 37 years) of regional towns (6 respondents from the town of Zdolbuniv of Rivne region, the garden № 1; 4 educators of Shepetivka, Khmelnytskyi region, the garden № 2; 4 respondents from the town of Zdolbuniv, Rivne region, garden № 5, Ukraine);

E6 - 19 teachers of the highest category (the experience of work is from 15 years and more, age is more than 37 years) of regional towns ( 5 respondents are from Zdolbuniv city of Rivne region, kindergarten № 1; 5 educators are from Shepetivka town of Khmelnytskyi region, kindergarten № 2; 9 respondents are from the town of Zdolbuniv, Rivne region, kindergarten № 5, Ukraine);

E7 - 19 directors of kindergartens (this group includes directors of cities and regional towns, such as: nursery schools № 2 and № 4 of Rivne, nursing schools № 5, 13, 14, 15, 18 of Kharkiv, nursery schools № 3 , 8, 9, 11 in Odessa, kindergarten № 1, 2 in Zdolbuniv, Rivne region, nurseries № 1, 2, 4 in town Shepetovka, Khmelnytskyi region, kindergartens № 1, 2, 5 in town Kamenets-Podolskyi, Khmelnytskyi region, Ukraine).

The results of the research and their discussion. This stage of the experiment was intended to analyze the understanding of the metaphorical meaning of the social situation by the teachers of pre-school educational 
institutions. We'd like to describe the results of the teachers for "the success of the allocation of the meaning on the basis of a holistic visual scheme of a particular situation without the isolation of partial details, that is, the understanding of the meaning intuitively".

According to this category, teachers of all groups, including the directors of preschool educational institutions, have the results above the average (according to the factor of procedure analysis): in E1 - 0.65, in E2 and E7 - 0.67, in E3 - 0.66, in E4 - 0.61, in E5 - 0.60, in E6 - 0.68. The results show that groups E1-E7 do not have statistically significant differences in this criterion. This means that the ability to intuitively correctly understand the meaning of proverbs from respondents is formed on the same level. However, at the level of the most positive trend, we can mark the results of two groups: E1 and E7. In these groups, the largest number of respondents intuitively allocates more than twelve proverbs. This may be due to the following peculiarities of the activity in these groups:

1) the respondents from group E1 and the directors of pre-school educational institutions (group E7) have a high level of the development of figurative generalization, which in our opinion contributes most to the correct intuitive allocation of the meaning from the ambiguous text of the proverb;

2) respondents from groups E1 and E7 in their pedagogical activity rely on intuitive decisions that are "provided" by personal and professional experience, in particular, the group E7 of institution managers, and solutions that are characterized by integrity and automatism. Thus, these respondents intuitively recognized the meaning of proverbs much better than respondents of other groups.

We will analyze the content side of the proverbs in order to understand which of the respondents most often refer to them as having a social meaning. Frequency of choice of teachers of preschool educational institutions for proverbs (or sentences) with social meaning in respondents' answers (which is also coincided with the choice of experts).

The results show us that the most common (more than $83 \%$ of respondents of all groups) understood the following proverbs as social: All work is noble (Будь-яка 
праия благородна). Doing is better than saying (Не мели язиком, а роби ділом). A good beginning makes a good ending (Який початок, такий $і$ кінець). Never put off till tomorrow what you can do today (Не відкладай на завтра те, щзо можна зробити сьогодні). Do not wait for a rainy day to fix your roof ( He треба чекати дощуового дня, щзоб полагодити даx). Slow but sure (Повільно, але вірно).

The second group of proverbs by frequency (it was selected by about $65-68 \%$ of respondents) includes: The devil finds work for idle hands to do. (Чорт знайде роботу для ледачих рук). Bear and forbear. (Проявляй терпіння та витримку). Business before pleasure. (Спочатку діло, потім розваги). No sooner said than done. (Сказано - як зав'язано). Great cry and l ittle wool. (Шуму багато, а толку мало). Chief cook and bottle washer. (І швець, і жнець і на дуді гравець). No sweat! (3 легкістю).

The third group of proverbs consists of those ones that were categorized by only some respondents. These are such proverbs as: What is learned in the cradle lasts to the grave. (Вивчене у колисиі пам'ятають до могили). The best way to get rid of work is to do it. (Найкращий спосіб позбутися роботи - зробити іï). Slow and steady win the race. (Тихіме їдеш - далі будеш). The cobbler's wife is the worst shod. (Чоботар ходить без чобіт). He that shoots oft, at last shall hit the mark. (Наполегливість усе здолає). Attempt not to fly like an eagle with the wings of a wren. (Не намагайся літати як орел, якщо маєш крила королька). Dоn't carry coals to Newcastle. (Не займайся непотрібною роботою). Rome was not built in a day. (Враз нічого не робиться). Jack of all trades is master in none. (Коли за все візьмешся - нічого не зробиш). Lazy people have the most labour. (Ледарі роблять вигляд, що працюють більше за всіх). He that is long a-giving knows not how to give. (Поки сонце зійде - роса очі виїсть). In doing we learn. (Хто багато робив, той багато знас).

The results of our research proved that the most respondents (63-65\%) refer these proverbs to objective ones, understanding their meaning based on the values of the words of the person. Summarizing these results, we have to assume that the 
degree of understanding the proverbs by the teachers depends on the level of generalization of social situations, having been expressed by them. So often there were cases when very specific meaning of the proverb with a high level of generalization was expressed by a single frame actualized in their sense social and substantive value. Respondents find it difficult to distinguish between contextual relationships and conceptual dependencies. Separating a substantive context with a holistic sense, giving it a system-forming function reduces the understanding of proverbs from the side of collecting and analysis specific features of the situation.

The next indicator that we have evaluated in the empirical research is "the success of the differentiation of the meaning of social situations in the process of intuitive understanding". The criterion for saying that it is the ability of erroneous assignment of these proverbs to a group of ones with social meaning. Since the group of respondents did not show their ability to understand social sense of proverbs intuitively, we will analyze the semantic frequency of the group of proverbs that respondents selected as social one. This criterion of analysis is based on the position of cognitive psychology on the existence of surface meanings of the phrase, which contains a special function - transferring of acquired personal meaning in the background of the existence of quasi-subjective significance of this phrase. We assume that the erroneous understanding of the proverb is due to the mediocre level of the development of social intelligence of teachers of pre-school educational institutions. It should be noted that the indicator "below the average" we considered in such a case when the respondent had more than four mistakes.

The results show us the insufficient (average) level of success according to the differentiation of the meaning of social situations in the conditions of its intuitive understanding. The factor weight according to this indicator in the groups of teachers in E1 and E7 is 0.38 , in the group E2 it is 0.34, in E3 it is 0.36 , in E4 it is 0.42 , in E5 it is 0.35 , in E6 it is 0.33 . These data are clearly consistent with the mediocre results of teachers and preschool education managers which were concerned with their level of the development of social intelligence, which also allows us to conclude that dance, artistic and musical activities have a lesser effect 
on the teacher's ability to understand more accurately and clearly the hidden meaning of the social situations, perhaps because these activities do not provide a detailed study of the elements of a holistic image. Therefore, the dominant role of this criterion belongs, nevertheless, to social intelligence.

Conclusions. The obtained empirical results of our research allow us to distinguish the following tendencies:

1) there are no statistically significant differences in the results of teachers of different groups (including the directors of pre-school educational institutions) according to the success of their interpretation of social meaning of proverbs and sayings;

2) teachers of pre-school educational institutions prevail over the following levels of understanding the meaning of proverbs (sayings), as the "level of concrete understanding" and the "level of global understanding";

3 ) insufficiently presented results for the "level of generalized understanding" (up to $16 \%$ ), which to our mind, has also negative influences on the level of the development of social intelligence of teachers of preschool educational institutions.

If we take into account that the level of understanding the meaning of proverbs (sayings) appears as a diagnostic feature of the subjective task of the respondent in the conditions of the need of the person for understanding and interpretation, then the level of specific understanding will be correlated with the task of recognition, and the level of global understanding has also positive correlation with the problems formulated as hypothesis. In this case, the structure of the results of the research of the levels of understanding of the teachers of preschool educational institutions and the directors of preschool institutions indicate that about $10 \%$ of respondents formulated the hypothesis in the sense of meaning, and approximately $30-35 \%$ of the teachers formulated them in the sense of being socially oriented, first of all, with the aim to obtain the recognition of meaning.

We have to emphasize significant contribution to the specific level of comprehension of proverbs in a general variety of levels of understanding in the profiles of teachers, with the peculiarities of the creative activity of respondents. 
The influence of the situational factor onto the conditions of performing creative activity facilitates the development of the ability of teachers to understand the situation in the form of compressed, circled inferences, prepared by the content of various other experiences of teachers, such as a recognition. The high results of teachers in accordance with the level of global understanding regarding the results of other respondents suggest that the content of personally meaningful experience appears as a functional determinant of understanding proverbs or sayings. The latter shows that the subjective experience was accumulated by teachers in the form of intuitive decisions in the context of individual professional activity. In such a way this subjective experience becomes for the respondents as a tool of understanding, above all, socially significant situations of interpersonal interaction.

\section{Literature}

1. Засєкіна Л.В. Профілі значення слова як функція когніції і культури [Текст] / Лариса Володимирівна Засєкіна // Наук. записки Острозької академії. Серія «Психологія і педагогіка». - Острог : Вид-во нац. ун.-ту «Острозька академія», 2010. - С. 66-75.

2. Клюева Н.В., Касаткина Ю.В. Учим детей общению [Текст] / Н.В. Клюева, Ю.В. Касаткина. - Ярославль, 1996. - 240 с.

3. Лабунская В.А. Экспрессия человека: общение и межличностное познание [Текст] / Вера Александровна Лабунская. - Ростов-н/Д. : Феникс, 1999. - 608 c.

4. Михайлова Е.С. Коммуникативный и рефлексивный компоненты и их соотношение в структуре педагогических способностей [Текст] : Дис. канд. психол. наук / Елена Сергеевна Михайлова. - Л. : Слово, 1990. - 238 с.

5. Новиков В.В. Социальная психология: Феномен и наука [Текст] / В.В. Новиков. - М. : Просвещение, 1998. - 489 с.

6. Смульсон М.Л. Місце самопроектування в проектній парадигмі [Електронний ресурс] / Марина Лазарівна Смульсон // Актуальні проблеми психології. - 2014. - Т. 2, Вип. 8. - С. 16-29. - Режим доступу : http://nbuv.gov.ua/UJRN/appsuh_2014_2_8_4. 
7. Смульсон М.Л. Проектування дистанційних розвивальних середовищ [Електронний ресурс] / Марина Лазарівна Смульсон. - Режим доступу : psytir.org.ua/index.php/technology.../22/6.

8. Смульсон М.Л. Психологія розвитку інтелекту : [монографія] / Марина Лазарівна Смульсон // [видання друге, виправлене та доповнене]. - К. : Норадрук, 2003. - 298 с. - (Інститут психології імені Г.С.Костюка АПН України).

9. Чеснокова О.Б. Изучение социального познания в детском возрасте [Текст] / Ольга Борисовна Чеснокова // Познание. Общество. Развитие / [сост. и ред. Д.В. Ушаков]. - М. : Ин-т психологии РАН, 1996. - С. 54-76.

10. Allport G.W. Personality : A Psychological Interpretation [Text] / Gordon Willard Allport. - N.-Y., 1937. - 516 p.

11. Cantor N.G., Kihlstrom J.F. Personality and social intelligence [Text] / N.G. Cantor, J.F. Kihlstrom. - N-Y. : Prentice-Hall, Inc. Englewood Cliffs, New Jersey, 1987. -420 p.

12. Elliott H.G.H. Emotional Intelligence-Based Leadership [Electronic resource] / H.G.H. Elliott. - Access mode : http://divcom.otago.ac.nz/mgmt/ research/03elliott.pdf.

13. Gardner H. Frames of mind: The theory of multiple intelligences [Text] / Howard Ear Gardner. - L. : Heinemann, 1983. - 178 p.

14. Guilford J.P. Is some creative thinking irrational? [Text] / Joy Paul Guilford // Journal of creative behavior. - 1982. - Vol. 16 (3). - P. 151-154.

15. Hunt T. The Measurement of social intelligence [Text] / T. Hunt // Journal of Applied Psychology, 1928. - P. 317-334.

16. Sternberg R. General intellectual ability [Text] / Robert Sternberg // Human abilities by R. Sternberg. - 1985. - P. 5-31.

17. Thorndike R.L. Intelligence and its uses [Text] / Robert Ladd Thorndike // Harper's Magazine. - 1920. - P. 227-235.

\section{References transliterated}

1. Zasiekina L.V. Profili znachennia slova yak funktsiia kohnitsii i kultury [Tekst] / Larysa Volodymyrivna Zasiekina // Nauk. zapysky Ostrozkoi akademii. Seriia 
«Psykholohiia i pedahohika». - Ostroh : Vyd-vo nats. un.-tu «Ostrozka akademiia», 2010. - S. 66-75.

2. Klyueva N.V., Kasatkina Yu.V. Uchim detej obshheniyu [Tekst] / N.V. Klyueva, Yu.V. Kasatkina. - Yaroslavl', 1996. - 240 s.

3. Labunskaya V.A. E'kspressiya cheloveka: obshhenie i mezhlichnostnoe pozna $\neg$ nie [Tekst] / Vera Aleksandrovna Labunskaya. - Rostov-n/D. : Feniks, 1999. $-608 \mathrm{~s}$.

4. Mixajlova E.S. Kommunikativnyj i refleksivnyj komponenty i ix sootnoshenie v strukture pedagogicheskix sposobnostej [Tekst] : Dis. kand. psixol. nauk / Elena Sergeevna Mixajlova. - L. : Slovo, 1990. - 238 s.

5. Novikov V.V. Social'naya psixologiya: Fenomen i nauka [Tekst] / V.V. Novikov. - M. : Prosveshhenie, 1998. - 489 s.

6. Smulson M.L. Mistse samoproektuvannia v proektnii paradyhmi [Elektronnyi resurs] / Maryna Lazarivna Smulson // Aktualni problemy psykholohii. - 2014. T. 2, Vyp. 8. - $\quad$ S. 16-29. - Rezhym dostupu : http://nbuv.gov.ua/UJRN/appsuh_2014_2_8_4.

7. Smulson M.L. Proektuvannia dystantsiinykh rozvyvalnykh seredovyshch [Elektronnyi resurs] / Maryna Lazarivna Smulson. - Rezhym dostupu : psytir.org.ua/index.php/technology.../22/6.

8. Smulson M.L. Psykholohiia rozvytku intelektu : [monohrafiia] / Maryna Lazarivna Smulson // [vydannia druhe, vypravlene ta dopovnene]. - K. : Noradruk, 2003. - 298 s. - (Instytut psykholohii imeni H.S.Kostiuka APN Ukrainy).

9. Chesnokova O.B. Izuchenie social'nogo poznaniya v detskom vozraste [Tekst] / Ol'ga Borisovna Chesnokova // Poznanie. Obshhestvo. Razvitie / [sost. i red. D.V. Ushakov]. - M. : In-t psixologii RAN, 1996. - S. 54-76.

10. Allport G.W. Personality : A Psychological Interpretation [Text] / Gordon Willard Allport. - N.-Y., 1937. - 516 p.

11. Cantor N.G., Kihlstrom J.F. Personality and social intelligence [Text] / N.G. Cantor, J.F. Kihlstrom. - N-Y. : Prentice-Hall, Inc. Englewood Cliffs, New Jersey, 1987. $-420 \mathrm{p}$. 
12. Elliott H.G.H. Emotional Intelligence-Based Leadership [Electronic resource] / H.G.H. Elliott. - Access mode : http://divcom.otago.ac.nz/mgmt/ research/03elliott.pdf.

13. Gardner H. Frames of mind: The theory of multiple intelligences [Text] / Howard Ear Gardner. - L. : Heinemann, 1983. - 178 p.

14. Guilford J.P. Is some creative thinking irrational? [Text] / Joy Paul Guilford // Journal of creative behavior. - 1982. - Vol. 16 (3). - P. 151-154.

15. Hunt T. The Measurement of social intelligence [Text] / T. Hunt // Journal of Applied Psychology, 1928. - P. 317-334.

16. Sternberg R. General intellectual ability [Text] / Robert Sternberg // Human abilities by R. Sternberg. - 1985. - P. 5-31.

17. Thorndike R.L. Intelligence and its uses [Text] / Robert Ladd Thorndike // Harper's Magazine. - 1920. - P. 227-235. 


\section{Відомості про автора:}

Івашкевич Едуард Зенонович - доктор психологічних наук, доцент, професор кафедри загальної психології та психодіагностики Рівненського державного гуманітарного університету (Рівне, Україна)

Ивашкевич Эдуард Зенонович - доктор психологических наук, доцент, профессор кафедры общей психологии и психодиагностики Ровенского государственного гуманитарного университета (Ровно, Украина)

Ivashkevych Eduard Zenonovych - Doctor of Psychology, Professor of the Department of General Psychology and Psychological diagnostics of Rivne State University of the Humanities (Rivne, Ukraine)

Моб. телефон: 8 (097) 382-76-69

E-mail Natasha1273@ukr.net

\subsubsection{8 року}




\section{РЕФЕРАТ НА СТАТТЮ}

\section{Е.З.ІВАШКЕВИЧА «СОЦАЛЬНИЙ ІНТЕЛЕКТ ПЕДАГОГІВ В КОНТЕКСТІ РОЗУМІННЯ НИМИ ПРИСЛІВ'ЇВ ТА ПРИКАЗОК»}

В статті соціальний інтелект педагогів дошкільних навчальних закладів проаналізовано в контексті розуміння особистістю значення прислів'їв та приказок, які вміщують так званий «соціальний» сенс. Автор статті вважає, що критеріями продуктивного функціонування соціального інтелекту педагога $є$ успішне розв'язання людиною соціальних нестандартних (в тому числі - оригінальних) задач та завдань, а також успішність фахівця в реалізації педагогічної діяльності. Зазначено, що перше передбачає обов'язкове функціонування механізму прийняття рішення. Обгрунтовано, що останній, як і інші функціональні механізми соціального інтелекту (механізм децентрації, механізм інтелектуальної ініціації, рефлексивні механізми тощо), зумовлюються когніціями особистості, наприклад, увагою, уявою, сприйманням, пам'яттю, мисленням та ін. Визначено, що в сфері мнемічного досвіду (мнемічний аспект соціального інтелекту) усвідомлені переживання супроводжуються почуттям суб'єктивної очевидності того, що відбувається. Саме за умов експліцитної наявності таких переживань суб'єкт здатний сам собі дати звіт про власний пережитий досвід.

Механізм прийняття соціально виваженого рішення було проаналізовано 3 урахуванням складності, нестандартності соціальної ситуації. Зазначено, що даний механізм дозволяє педагогу відійти від інтелектуальних утворень людини як представника певного національно-культурного простору, та, уникаючи прототипів та етнічних стереотипів, обрати найбільш доцільний даній соціальній ситуації механізм актуалізації відображення суб'єктивного простору, когнітивний стиль виконання професійної діяльності, та, вибудовуючи логіку розвитку ситуацій міжособистісної взаємодії, ураховуючи моральні та етнічні норми, цінності тощо, прийняти соціально виважене рішення. Останнє сприятиме не лише тому, що педагог буде адекватно та емпатійно здійснювати взаємодію 3 іншими суб’єктами 
(колегами та підопічними особами), а й, в тому числі, досягненню педагогом успіху в професійній діяльності. У функціональному аспекті йдеться про ампліфікацію соціального інтелекту.

Отримані емпіричні результати проведеного дослідження дозволили виділити наступні тенденції: 1) немає статистично значущої різниці в результатах педагогів різних груп (в тому числі - і керівників дошкільних навчальних закладів) за успішністю інтерпретації соціального смислу на прислів’ї та приказок; 2) у педагогів дошкільних навчальних закладів переважають результати за такими рівнями розуміння сенсу прислів'їв (приказок), як «рівень конкретного розуміння» та «рівень глобального розуміння».

Ключові слова: соціальний інтелект, індивідуальне пізнання, увага, уява, сприйняття, пам'ять, мислення. 